\title{
Neuroprotective Effects of Ethyl Acetate Extract of Zingiber zerumbet (L.) Smith against Oxidative Stress on Paraquat-Induced Parkinsonism in Rats \\ (Kesan Neurolindungi Ekstrak Etil Asetat Zingiber zerumbet (L.) Smith terhadap Tekanan Oksidatif pada Tikus Parkinsonisme Aruhan Parakuat)
}

\author{
FARAH WAHIDA IBRAHIM, UMI NORAASHIKIN ZAINUDIN, MAZLYZAM ABDUL LATIF \& ASMAH HAMID*
}

\begin{abstract}
Zingiber zerumbet has been traditionally used as an anti-inflammation and antioxidant agent. The present study investigates the neuroprotective effects of ethyl acetate extract of Z. zerumbet against oxidative stress on paraquat $(P Q)$-induced Parkinsonism in rats. Forty male Sprague-Dawley rats were divided into five groups: Negative control (normal saline), positive control ( $\mathrm{N}$-acetylcysteine, $N A C 20 \mathrm{mg} / \mathrm{kg}+P Q 10 \mathrm{mg} / \mathrm{kg}$ ), PQ only, $200 \mathrm{mg} / \mathrm{kg} \mathrm{Z}$. zerumbet + $P Q$ and $400 \mathrm{mg} / \mathrm{kg} \mathrm{Z}$. zerumbet $+P Q$. The extract was given orally for 19 consecutive days and $P Q$ was administered intraperitoneally on day 8-12th of the treatment regime. Both serum and fresh brains containing substantia nigra (SN) region were taken for biochemical and histological analysis. Administration of both 200 and $400 \mathrm{mg} / \mathrm{kg}$ ethyl acetate $\mathrm{Z}$. zerumbet extracts to the PQ-treated groups have resulted in: Decreased levels of MDA and PC in the SN homogenates; and increased SOD, GPX; and CAT activities in the SN and serum. Overall, ethyl acetate extract of Z. zerumbet reduced oxidative stress in the $S N$ of $P Q$-induced neuronal damages, therefore, has the potential to be developed as a preventive agent for neurodegenerative disorders caused by environmental toxins.
\end{abstract}

Keywords: Antioxidant; oxidative stress; paraquat; Parkinson's disease; Zingiber zerumbet

ABSTRAK

Zingiber zerumbet telah digunakan secara tradisi sebagai agen anti-keradangan dan antioksidan. Kajian ini dijalankan untuk mengkaji kesan neurolindungi ekstrak etil asetat Z. zerumbet terhadap tekanan oksidatif dalam tikus Parkinsonisme aruhan parakuat (PQ). Empat puluh tikus Sprague-Dawley jantan dibahagikan kepada lima kumpulan: Kawalan negatif (salin normal), kawalan positif ( $\mathrm{N}$-asetilcysteine, $N A C 20 \mathrm{mg} / \mathrm{kg}+P Q 10 \mathrm{mg} / \mathrm{kg}$ ), PQ sahaja, $200 \mathrm{mg} / \mathrm{kg} \mathrm{Z}$. zerumbet $+P Q$ dan $400 \mathrm{mg} / \mathrm{kg} \mathrm{Z}$. zerumbet $+P Q$. Ekstrak diberikan secara oral gavaj selama 19 hari berturut-turut dan $P Q$ diberikan secara intraperitoneal pada hari ke-8 sehingga ke-12 rejim rawatan. Kedua-dua sampel serum dan tisu otak pada bahagian substantia nigra (SN) diambil untuk analisis biokimia dan histologi. Pemberian ekstrak etil asetat Z. zerumbet pada kedua-dua dos 200 dan $400 \mathrm{mg} / \mathrm{kg}$ kepada kumpulan yang dirawat PQ telah: Menurunkan tahap MDA dan PC dalam homogenat SN; meningkatkan aktiviti SOD, GPX, dan CAT dalam SN dan serum; serta meningkatkan aras glutation terturun (GSH) dalam SN. Secara keseluruhannya, ekstrak etil asetat Z. zerumbet didapati dapat mengurangkan tekanan oksidatif pada kawasan SN di otak tikus yang diaruh kerosakan neuron oleh PQ. Seterusnya, berpotensi untuk dibangunkan sebagai agen pencegah gangguan penyakit neurodegeneratif yang disebabkan oleh pendedahan terhadap toksin dari alam sekitar.

Kata kunci: Antioksidan; parakuat; penyakit Parkinson; tekanan oksidatif; Zingiber zerumbet

\section{INTRODUCTION}

Parkinson's disease (PD) is the second most common neurodegenerative disorder after Alzheimer's disease (Yokohama et al. 2008). Parkinson's disease exerts an enormous impact on the lives of affected individual, their families and also the society (Giasson et al. 2002). Metaanalysis of 27 international studies showed that PD affects both gender, with increasing number of incidence as age advances. Though the number is higher in males at all age groups, further analysis showed that the incidence affecting the males is significantly higher in the 60-69 and 70-79 age groups compared to the women of the same age groups (Hirsch et al. 2016).
$\mathrm{PD}$ is the result of selective loss of dopaminergic neurons in the substantia nigra pars compacta (SNpc) (McCollum et al. 2010). It also involves an abnormal deposition of intracellular inclusions or Lewy bodies within the brain (Lewis \& Cookson 2012). Lewy bodies are protein aggregates composed mainly of $\alpha$-synuclein and ubiquitin (Blesa et al. 2012). Effects from the loss of striatal dopamine and dysfunction of the nigrostriatal pathway resulted in a group of motor symptoms such as rigidity, tremor, bradykinesia and postural imbalance (Seet et al. 2010). Although the pathogenesis of this disease is still unclear, it is considered to be potentiated by the interaction between two factors; environment and genetic (Shafique et 
al. 2011). It is well known that exposure to environmental herbicides is one of the environmental factors that have been reported to contribute to the pathogenesis of PD (Shafique et al. 2011). However, the risk of PD in human is reported to be higher in those with paraquat exposure and having the defective gene that encodes glutathione S-transferase T1 (GSTT1)(Goldman et al. 2012).

Paraquat (1, 1 'dimethyl-4,4'-bipyridinium) is among the most commonly used herbicides in the agricultural sector worldwide (Cha et al. 2014). Paraquat (PQ) is a highly toxic quaternary ammonium herbicide that has been shown to produce toxicity particularly in the dopaminergic neurons of the rat and mouse brains (Blanco-Ayala et al. 2014; Yang \& Tiffany-Castiglioni 2005). PQ is structurally similar to 1-methyl-4-phenylpyridinium ion $\left(\mathrm{MPP}^{+}\right)$, a known neurotoxic and the active metabolite of 1-methyl4-phenyl-1,2,3,6-tetrahydropyridine or MPTP (Brooks et al. 1999). Both PQ and MPTP ultimately cause the loss of dopaminergic neurons in the SN that leads to the clinical symptoms of Parkinsonism (Wesseling et al. 2001). PQ is considered as a potent oxidative stress inducer (Lascano et al. 2012). Oxidative stress plays a major role in the pathogenesis of Parkinson's disease through the induction of nigral dopaminergic neuronal cells death (Nikolova et al. 2012). The death of these neuronal populations by PQ is mainly attributed to impaired mitochondrial functions as well as increased production of reactive oxygen species and reduction in oxygen consumption (Blanco-Ayala et al. 2014; Huang et al. 2016). PQ specific toxicity to dopaminergic neurons via oxidative stress mechanism in rats has prompted the current study to utilize the PQ-induced Parkinsonism model in order to study the antioxidant strategies of a herbal plant namely Zingiber zerumbet against Parkinsonism.

Herbal medicine has gain lots of attention due to the presence of various natural compounds that are beneficial to health including alleviating pathological symptoms. Zingiberaceae belong to order of Zingiberales, which forms an isolated group among the monocotyledons. Approximately 1000 species of Zingiberaceae are found in tropical Asia. In Peninsular Malaysia there are more than 160 species of Zingiberaceae identified (Abdul et al. 2008). Only a small portion of these ginger species have been cultivated for its use as vegetables, condiments, spices, flavors, dyes, medicines as well as ornaments (Habsah et al. 2000).

Zingiber zerumbet has been claimed to have high medicinal values (Yob et al. 2011). Zingiber zerumbet or locally known as lempoyang is used in local traditional medicine as a remedy for swelling, sores and loss of appetite (Abdul et al. 2008). The rhizome of Z zerumbet has been used for anti-inflammation, anti-ulceration, antioxidant, anti-pyretic, analgesic and anti-microbe (Somchit et al. 2005). This rhizome is reported to contain alkaloid, saponin, flavonoids and polyphenol as well as the volatile oil (Batubara 2013). The volatile oil of $Z$. zerumbet contains zerumbone as its main active constituent (Bhuiyan et al. 2009). Among the differences in the extraction methods employed, ethyl acetate extraction gives the highest yield of zerumbone (51.57\%) (Budin et al. 2013). Zerumbone has versatile pharmaceutical properties including anti-inflammatory, antitumor, antioxidant, antimicrobial and antinociceptive activities (Somchit et al. 2012). Zerumbone has also been reported to inhibit proliferation of leukemic, cervical, ovarian, colon, breast and liver cancers (Abdelwahab et al. 2012, 2011).

As a neuroprotective agent, an administered substance of interest should be able to reverse some of the pathological damage or prevent further damage to the neuronal cells. A lot of study has found that active compounds present in the natural products have high contents of antioxidant and anti-inflammatory properties. These properties can protect the neurons against neurodegenerative conditions thereby preserving or even enhancing cognitive function (Essa et al. 2012; Hamid et al. 2018). Z. zerumbet extracts and the pure compound, Zerumbone, fit the ideal characteristics of a neuroprotective drug due to their anti-inflammatory, antioxidant and antiplatelet aggregate activities as reviewed in Yob et al. (2011).

In the current study, the main aim is to investigate the neuroprotective potential of ethyl acetate extract of Z. zerumbet rhizome through its antioxidants activities in paraquat-induced Parkinsonism in rats. The effects were determined by measuring the levels of oxidative stress markers (malondialdehyde (MDA), protein carbonylation), endogenous antioxidants (GSH, superoxide dismutase (SOD), catalase), histological changes of the neurons in the SN and behavioral analysis.

\section{MATERIALS AND METHODS}

\section{PLANT MATERIALS}

Fresh rhizomes of $Z$. zerumbet were collected from Temerloh, Pahang. The specimen was first validated and kept in the Herbarium, Faculty of Science and Technology (FST), Universiti Kebangsaan Malaysia (voucher number is UKMB-29952). The rhizomes were scrubbed and cleaned, chopped finely using dry blender and then air-dried at room temperature for three days.

\section{PLANT EXTRACTION}

The air-dried chopped rhizomes were soaked at room temperature in $100 \% n$-hexane. After $72 \mathrm{~h}$, the hexane containing the chopped rhizomes was filtered, the resulting filtrate (hexane) was kept for the next stage and the rhizome residue was soaked again for $72 \mathrm{~h}$ with a fresh hexane. This cycle was repeated 3 times. The rhizome residue from the third cycle of hexane was soaked with another solvent, $100 \%$ fresh ethyl acetate and later with $100 \%$ methanol, following the same exact procedure as hexane. The resultant solvent extracts (filtrates) collected at each stage were evaporated using rotavapor apparatus to yield dried crude extracts of hexane, ethyl acetate and methanol. All the crude extracts were stored at $4^{\circ} \mathrm{C}$ until further use. 
Prior to use, the Z. zerumbet ethyl acetate extract was dissolved in $100 \%$ dimethyl sulfoxide (DMSO) and diluted in phosphate buffered saline (PBS; pH7.4), aliquoted and kept as stock at $-20^{\circ} \mathrm{C}$.

\section{EXPERIMENTAL PROTOCOL}

The procedures involving the use of laboratory animals were approved by the UKM Animal Ethical Committee (UKMAEC) with the following approval code reference: FSK/BIOMED/2013/ASMAH/14-NOV.15566-NOV.-2013JUNE-2014. Forty male Sprague-Dawley rats aged 6-8 weeks (140-200 g) were purchased from the UKM Laboratory Animal Resource Unit. The animals were housed in a controlled environment with room temperature at $24^{\circ} \mathrm{C} \pm 1$ and a 12 -h light/dark cycle. Food and water were provided ad libitum. Rats were randomly divided into five groups with $n=7$ /group. The groups were negative control group (normal saline), NAC (N-acetylcysteine) + PQ (20 mg/kg of NAC with PQ), PQ (PQ treated-group), $200+\mathrm{PQ}(200 \mathrm{mg} / \mathrm{kg}$ Z. zerumbet with PQ) and $400+\mathrm{PQ}$ (400 mg/kg of $Z$. zerumbet with PQ). Ethyl acetate extract of $Z$. zerumbet was given orally for 19 consecutive days and PQ was administered intraperitoneally $(10 \mathrm{mg} / \mathrm{kg})$ on Day 8-12 of the treatment regime. Both serum and fresh brains containing the $\mathrm{SN}$ region were taken for biochemical and histological analysis. Research timeline is shown in Figure 1.

\section{EXPERIMENTAL TIMELINE}

Zingiber zerumbet extract was given to the respective groups for 19 days consecutively via oral gavage (Day-1 - Day-19) (Figure 1). Respective groups of animals were injected intraperitoneally with paraquat daily from Day8 until Day-12 of the treatment regime and behavioural changes were observed. On Day-20, rats from all groups were killed and sampling was done. Both fresh brains containing SN and serum were taken for further analysis.

\section{SAMPLE PREPARATION}

For the $Z$. zerumbet treatment group, the animals were killed $24 \mathrm{~h}$ after the last dose of $Z$. zerumbet extract on Day-19. Regardless of treatment, all animals were killed on Day-20. Prior to killing, the animals were anesthetized with KTX (Ketamine, xylazine and zoletil) with dosage of $0.5 \mathrm{~mL} / \mathrm{kg}$ (Hamid et al. 2018) and decapitated to collect trunk blood and brains for sampling. Blood was collected in plain tubes and allowed to coagulate at room temperature for $3 \mathrm{~h}$. Serum was obtained after centrifugation at $3000 \mathrm{rpm}$ for $10 \mathrm{~min}$ and stored at $-20^{\circ} \mathrm{C}$ until further use. The SN area was identified and isolated using brain matrices (Tedpella, USA) and washed with iced-cold $\mathrm{KCl}$ to wash off traces of blood. For histological purposes, the brain slice containing SN was fixed in $10 \%$ formalin, while for biochemical analysis; the SN was minced into small pieces, weighed and homogenized with $1: 15 \% \mathrm{KCl}$ solution at a ratio of $3 \mathrm{~mL} / \mathrm{g}(\mathrm{v} / \mathrm{w})$. The brain homogenate was then centrifuged at $4000 \mathrm{rpm}$ for $20 \mathrm{~min}$ at $4^{\circ} \mathrm{C}$. The supernatant obtained was then stored at $-20^{\circ} \mathrm{C}$ until further analysis.

\section{BEHAVIORAL OBSERVATION}

Tremor Tremor is one of the clinical hallmarks of PD. This behavioral study was performed to verify the Parkinsonism symptoms which were manifested in the PQ-induced rats. The phasic tremor of the whole body was evaluated and scored according to Coward et al. (1977); 0, no tremor; 1, occasional isolated twitches; 2 , moderate or intermittent tremor associated with short periods of calmness; and 3, pronounced continuous tremor.

\section{BIOCHEMICAL ANALYSIS}

Total Protein Total protein determination was based on Bradford (1976) method. Standard curve was prepared from a $500 \mu \mathrm{g} / \mathrm{mL}$ of bovine serum albumin (BSA) by pipetting $0.2,0.4,0.6,0.8$ and $1.0 \mathrm{~mL}$ of the solution into glass tube. The concentration of the measured proteins was plotted against the corresponding absorbance resulting in a standard curve which was used to determine the protein concentration in the samples. Depending on the concentration, diluted serum and SN supernatant were pipetted into test tubes separately. The volume was adjusted to $0.1 \mathrm{~mL}$ with PBS. A total of $5 \mathrm{~mL}$ of protein reagent was added to the test tubes and the contents were mixed by mild vortexing. The measurement of the absorbance was done at $595 \mathrm{~nm}$ against a reagent blank prepared from $0.1 \mathrm{~mL}$ of the appropriate buffer and $5 \mathrm{~mL}$ of protein reagent. The readings were taken between 2 min to $1 \mathrm{~h}$.

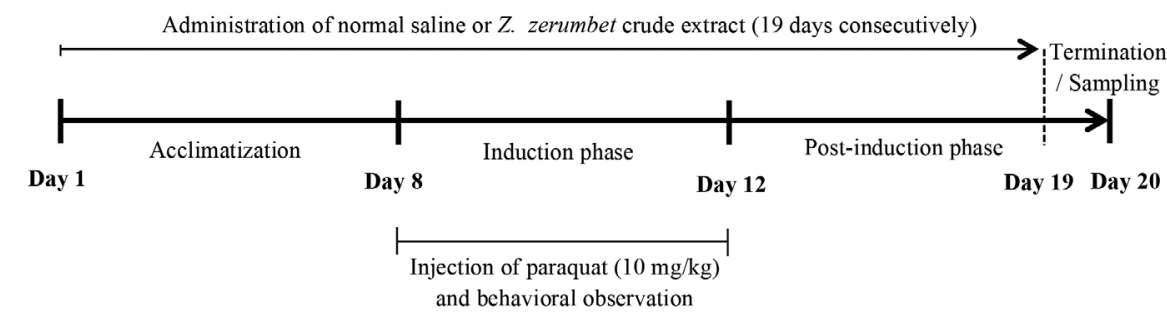

FIGURE 1. The experimental timeline. Zingiber zerumbet extract was given for 19 days consecutively via oral gavage. Then, on Day- 8 until Day-12, the paraquat was injected daily (i.p) and the behavioural changes were observed. On Day-20, all the rats were sacrificed and sampling was done. Both fresh brains containing SN and serum were taken for further biochemical and histological analysis 
Malondialdehyde (MDA) Level The formation of thiobarbituric acid reactive substances (TBARS), which are the byproduct of lipid peroxidation, was measured according to the method by Ledwozyw et al. (1986). In this assay, the presence of reactive aldehyde such as MDA (end product of lipid peroxidation) reacts with thiobarbituric acid (TBA) reagent under an acidic condition to generate a pink coloured product. A total of $0.1 \mathrm{~mL}$ of SN homogenate supernatant was added to $0.4 \mathrm{~mL}$ of distilled water. The mixture was then added with $2.5 \mathrm{~mL}$ of trichloroacetic acid (TCA) and left to incubate at room temperature for $15 \mathrm{~min}$. Then $1.5 \mathrm{~mL}$ of TBA was added and the resultant mixture was heated in a water bath at $100^{\circ} \mathrm{C}$ for $30 \mathrm{~min}$ or until a faint pink coloured solution was obtained. After cooling, the coloured product was added with $1 \mathrm{~mL}$ of butanol, vortexed for $3 \mathrm{~min}$ and the top layer of the resulting mixture was taken and the absorbance was measured using spectrophotometer at $532 \mathrm{~nm}$.

Protein Oxidation Level (Protein Carbonyl, $(P C)$ ) Protein oxidation was evaluated by the determination of protein carbonyl level. Dinitrophenylhydrazine (DPNH) reacts with protein carbonyl groups to produce the stable 2, 4-dinitrophenyl (DNP) hydrazine protein adducts that can be detected spectrophotometrically at $370 \mathrm{~nm}$ according to the method by Levine et al. (1990). In short, proteins were precipitated by the addition of $20 \%$ TCA and were dissolved in (how much of DPNH). The results were reported as $\mathrm{nmol} / \mathrm{mg}$ protein.

Superoxide Dismutase (SOD) Activity Superoxide dismutase activity was measured according to the method of Beyer and Fridovich (1987). In summary, the reaction mixture consisting of $50 \mathrm{mM}$ potassium phosphate buffer pH7.8, 0.1 mM EDTA, 9.9 mM L-methionine, $5.7 \times 10^{-5}$ nitro blue tetrazolium (NBT) and $2.5 \times 10^{-2} \%(\mathrm{w} / \mathrm{v})$ Triton X-100 and riboflavin $(0.01 \mathrm{~mL}$ of $4.4 \%)$ were freshly prepared on the day of the assaying. A total of $1.0 \mathrm{~mL}$ of the reaction mixture was added to $20 \mu \mathrm{L}$ of SN homogenate in a cuvette to initiate the reaction which was then placed in a box illuminated with $20 \mathrm{~W}$ neon lamps for $7 \mathrm{~min}$. The reduction of NBT was measured at $560 \mathrm{~nm}$ spectrophotometrically. The results were calculated by subtracting the changes in absorbance of the blank from the sample and dividing $\Delta \mathrm{A}$ by 0.012 to obtain the McCord-Fridovich units of activity.

Catalase (CAT) Activity Catalase activity was determined as described by Aebi (1984). A total of $50 \mathrm{mM}$ phosphate buffer $(\mathrm{pH} 7.0)$ and $30 \% \mathrm{H}_{2} \mathrm{O}_{2}$ were freshly prepared on the day of the assaying. Two $\mathrm{mL}$ of sample solution was mixed with $1 \mathrm{~mL}$ of $\mathrm{H}_{2} \mathrm{O}_{2}$. The decomposition of $\mathrm{H}_{2} \mathrm{O}_{2}$ was measured at $240 \mathrm{~nm}$ via spectrophotometer using a blank containing $2 \mathrm{~mL}$ of the sample solution and $1 \mathrm{~mL}$ of phosphate buffer. The reaction time was ensured to be within $30 \mathrm{~s}$.

Glutathione Peroxidase (GPx) Activity Glutathione peroxidase measurement was determined at $340 \mathrm{~nm}$ spectrophotometrically using the method of Paglia and Valentine (1967). Both the blank and the system cuvettes contained $0.1 \mathrm{M} \mathrm{KPO}_{4}$ buffer (pH7.0), $2 \mu \mathrm{M}$ EDTA, 10 units $/ \mathrm{mL}$ glutathione reductase, $4 \mathrm{mM}$ sodium azide, 200 mM NADPH and sample. In addition, the system cuvette contained $1.0 \mathrm{mM}$ glutathione, GSH. After $10 \mathrm{~min}$ of preincubation at $37^{\circ} \mathrm{C}$, the reaction was started by adding 1.0 $\mathrm{mM} \mathrm{H} \mathrm{H}_{2} \mathrm{O}_{2}$ to the blank and system cuvettes. In order to correct the non-enzymatic oxidation of GSH and NADPH by $\mathrm{H}_{2} \mathrm{O}_{2}$, an additional blank assay in which the buffer was substituted for the sample was performed

Glutathione (GSH) Level The assay of GSH with DTNB was performed by following Ellman's method (1959). Equal volume of $20 \%$ trichloroacetic acid (TCA) containing 1 mM EDTA was added to the brain homogenate to precipitate the tissue protein. After $5 \mathrm{~min}$, the resulting mixture was centrifuged for $10 \mathrm{~min}$ at $200 \mathrm{rpm}$. A total of $200 \mu \mathrm{L}$ of the supernatant was transferred to a new set of test tubes and added with $1.8 \mathrm{~mL}$ of the Ellman's reagent, 5, 5'dithio bis2nitrobenzoic acid (DTNB). The resulting solution was measured at $415 \mathrm{~nm}$ against a blank. Absorbance values were compared with a standard curve generated. The GSH level was measured in $\mathrm{nmol} / \mathrm{mg}$ protein.

\section{HISTOLOGICAL ANALYSIS}

Histological examination on the region of interest of the brain was performed according to routine histological techniques. Briefly, after the animal was killed, the brain containing the SN region was isolated and harvested, rinsed in normal saline and sectioned into small pieces. The sectioned tissues were then fixed in $10 \%$ formalin, dehydrated in stepwise increasing concentration of ethanol solution (50\% to $100 \%)$ and later embedded in paraffin. Tissue sections of $5 \mu \mathrm{m}$ thickness were produced using microtome and fixed overnight on slides. The slides were subsequently stained with hematoxylin and eosin (H\&E) and then analyzed under a light microscope (Motic Images, Hong Kong).

\section{STATISTICAL ANALYSIS}

Statistical analysis was done using SPSS version 20.0 (IBM Corp., AS). Data was first analyzed using Shapiro-Wilk normality test. Later, one way analysis of variance (ANOVA) was employed to compare means between groups followed by posthoc Tukey test. Mixed ANOVA was used to analyze the differences in the tremor score. Data was expressed as means \pm standard error of mean (SEM) with $p<0.05$ was considered as statistical significance.

\section{RESULTS}

\section{TREMOR OBSERVATION}

Tremors observed in the rats were evaluated and scored. In short, a score of 0 means absence of tremor, 1 indicates 
occasional isolated twitches being observed, 2 indicates moderate or intermittent tremor associated with short periods of calmness, whereas a score of 3 indicates that the rats showed pronounced continuous tremor. Higher score indicates the severity of the symptoms shown (Figure 2). There was a noted decline in the tremor score for both 200 and $400 \mathrm{mg} / \mathrm{kg}$ extract group compared to the PQ-treated group as seen in the post-induction period. Administration of $Z$. zerumbet in both the extract groups alleviated the severity of the tremors caused by PQ induction.

\section{EFFECTS OF Z. ZERUMBET EXTRACT ON OXIDATIVE STRESS MARKERS}

Administration of PQ for five consecutive days induced oxidative stress in the SN area as indicated by a significant increase in the level of protein carbonyl (Figure 3(B)). Induction of $\mathrm{PQ}$ in the $\mathrm{Z}$. zerumbet treatment groups of both $200+$ PQ and $400+$ PQ showed significantly reduced levels of MDA and protein carbonyl when compared to the PQ-treated group $(p<0.05)$.

\section{EFFECTS OF Z.ZERUMBET EXTRACT ON ANTIOXIDANT STATUS}

Administrations of PQ for five consecutive days also caused a significant reduction in the activities of CAT (Figure 3(D)) and GPx (Figure 3(E)) in the SN. In contrast, administration with either 200 or $400 \mathrm{mg} / \mathrm{kg}$ of Z zerumbet extract significantly prevented the decreased in the enzyme levels and improved the activities of SOD (Figure 3(C)), CAT (Figure 3(D)) and GPx (Figure 3(E)) $(p<0.05)$. In the serum, paraquat induction caused a significant reduction of SOD (Figure 4(A)) and CAT (Figure 4(B)) enzyme activities compared to the normal control group $(p<0.05)$. However, administration of $Z$. zerumbet at $400 \mathrm{mg} / \mathrm{kg}$ increased both of these enzyme activities significantly when compared to the PQ-treated group $(p<0.05)$.

\section{HISTOLOGICAL OBSERVATION}

Histological sections of the brain sample containing the SN region was scrutinized under a light microscope. There was presence of fibrillary aggregates called Lewy bodies (LBS) in the SN of the PQ-treated group (Figure 4(D)). In our observation, administration of PQ caused the formation of fragmentation in the nucleus of the neurons and the presence of Lewy bodies. In contrast, administration of $Z$. zerumbet extract prevented the nucleus from undergoing fragmentation and thus appeared intact and normal (Figure 4(E)).

\section{DISCUSSION}

In $\mathrm{PD}$, there is growing evidence that oxidative stress mechanism play a role in causing neuronal cell death. In this study, administration of $10 \mathrm{mg} / \mathrm{kg}$ of PQ for five consecutive days was able to induce Parkinsonism in rats as demonstrated by behavioral observation (tremor). Co-administration of ethyl acetate extract of $Z$. zerumbet with PQ showed that there was a reduction in the oxidative stress level in Parkinsonism rats compared to the group that was given only PQ. Furthermore, the protective effect of $Z$. zerumbet was found to be more remarkable in the $400+$ PQ group than in the $200+$ PQ group. This finding is in line with previous study conducted by Hamid et al. (2011) on hepatoprotective effects of the same extract. In that study, they have shown that $400 \mathrm{mg} / \mathrm{kg}$ of $Z$. zerumbet ethyl acetate extract gave a better hepatoprotective effects to the paracetamol-induced hepatotoxicity rats compared to the $200 \mathrm{mg} / \mathrm{kg}$ dosage.

Oxidative stress is an imbalance between the production of ROS and an antioxidant defense system to detoxify the reactive intermediates or to repair the resulting damage (Betteridge 2000). Excessive in ROS production or impaired antioxidant system will lead to oxidative

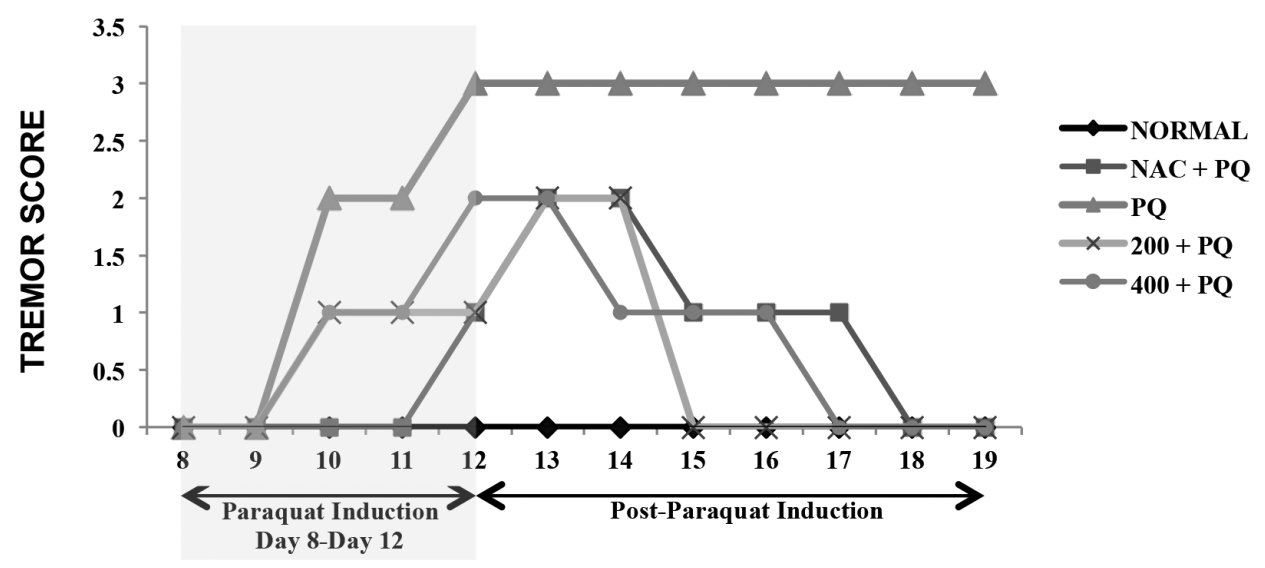

FIGURE 2. Tremor score. Tremor is evaluated based on scoring, the higher the score, the more severe the symptoms shown. All animals scored 0 prior to paraquat induction. Based on the graph, there was a decreased in the tremor score for both the extract supplemented groups compared to PQ-treated group. Administrations of Z. zerumbet from Day 1 - Day $19(200 \mathrm{mg} / \mathrm{kg}$ and $400 \mathrm{mg} / \mathrm{kg})$ alleviated the severity of the tremor during the induction period. Mixed ANOVA test revealed significant differences in all groups $(p<0.05)$ during paraquat induction (Day 8-Day 12 ). 

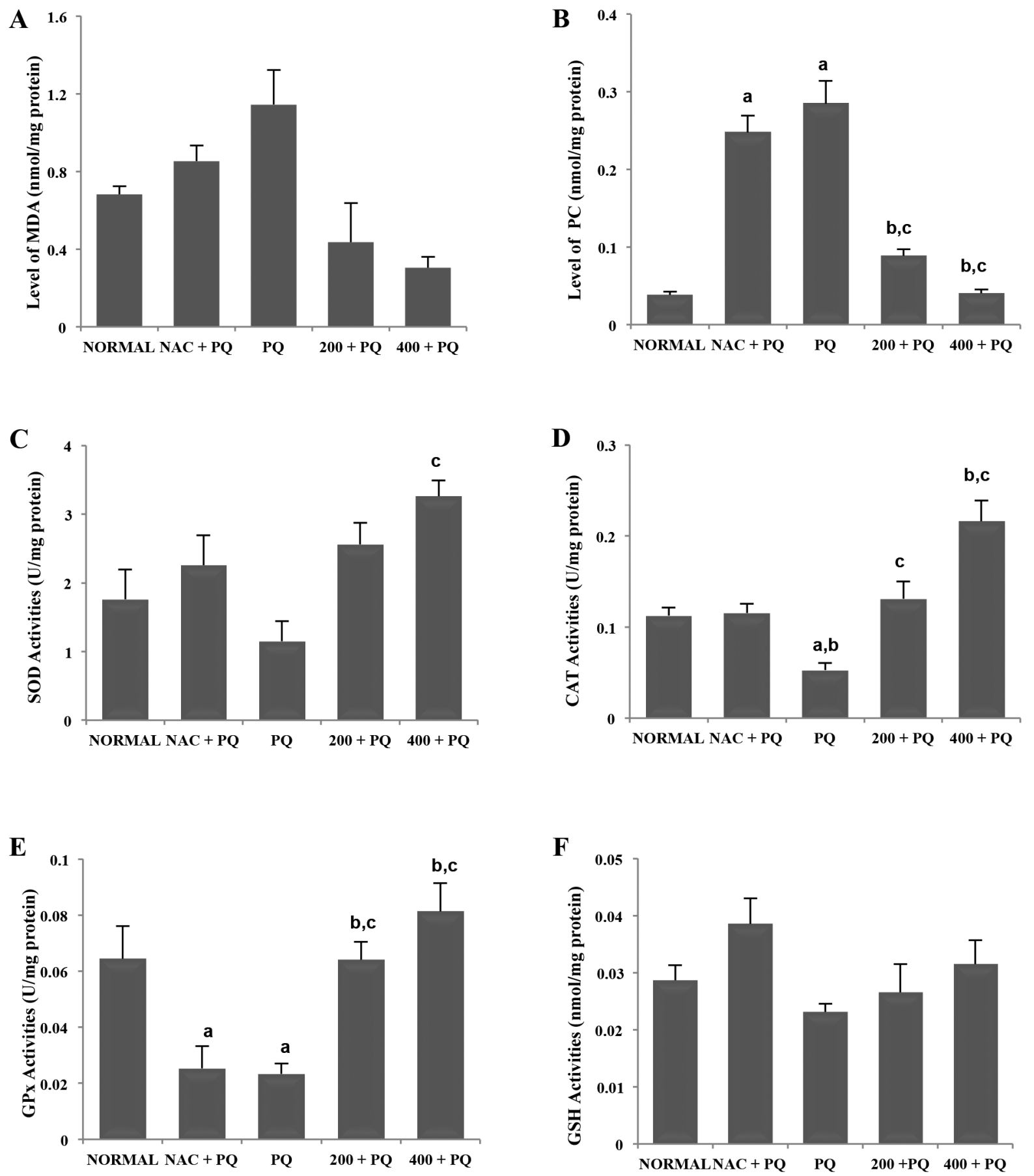

FIGURE 3. Oxidative stress markers and antioxidant status in the substantia nigra. Paraquat (PQ) induction for 5 consecutive days resulted in lower CAT (D) and GPX (E) enzyme activities with a significant increase in the PC level in the SN (B) $)^{\mathrm{a}}$. Zingiber zerumbet administration reduced the impact of PQ-induced oxidative stress as evidenced by lower levels of MDA (A) and PC (B) in both 200 and $400 \mathrm{mg} / \mathrm{kg}$ groups $^{\mathrm{c}}$. The reduction in the level of oxidative stress might be contributed by increased activities of antioxidant enzymes; SOD (C) CAT (D) and GPx activities (E) ${ }^{c}$. Data are presented as mean \pm SEM with ${ }^{\text {a }}$ significant comparison against normal control group $(p<0.05)$, ${ }^{b}$ significant comparison against positive control group (NAC $\left.+\mathrm{PQ}\right)(p<0.05)$ and ${ }^{\mathrm{c}}$ significant comparison against PQ-treated group $(p<0.05)$

imbalance and can cause ROS overproduction. Disruption in the normal redox state of cells can cause toxic effects through the production of peroxides and free radicals that damage all components of the cell, including proteins, lipids and DNA (Poljsak et al 2013).
In this study, both MDA and the PC levels were observed to increase in the PQ-treated group, with only the PC level was statistically proven to be significantly higher compared to the normal control group. Malondialdehyde (MDA) is one of the most frequently used indicator of lipid 
A
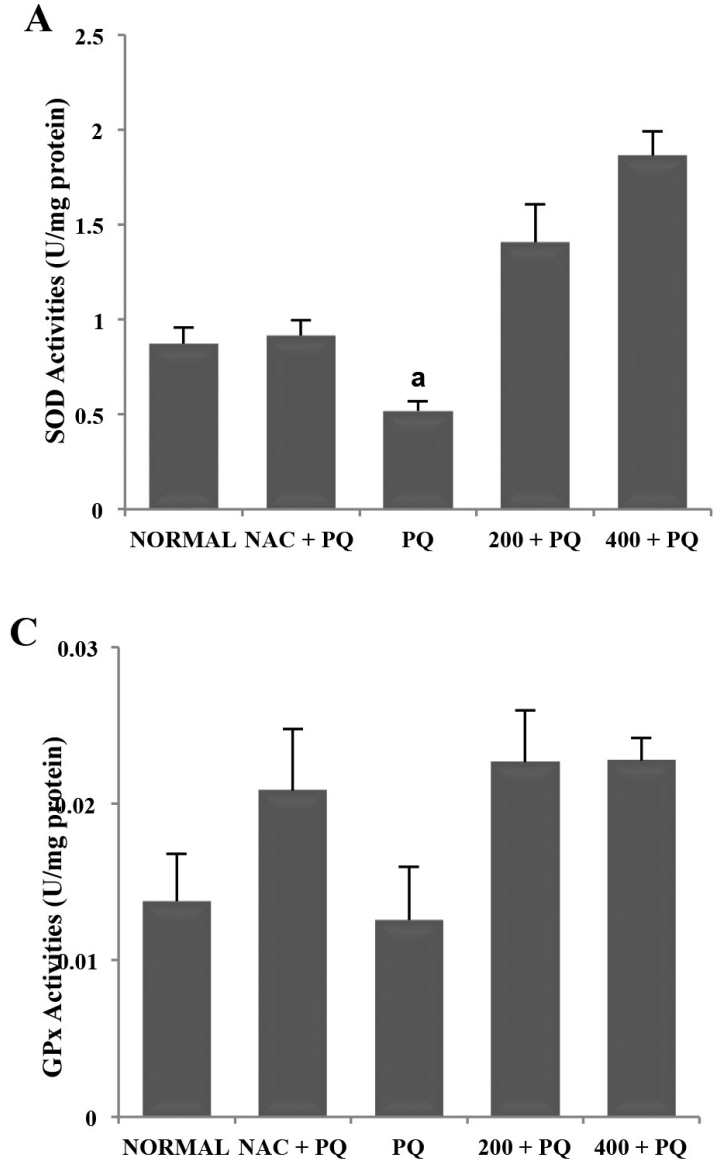

B
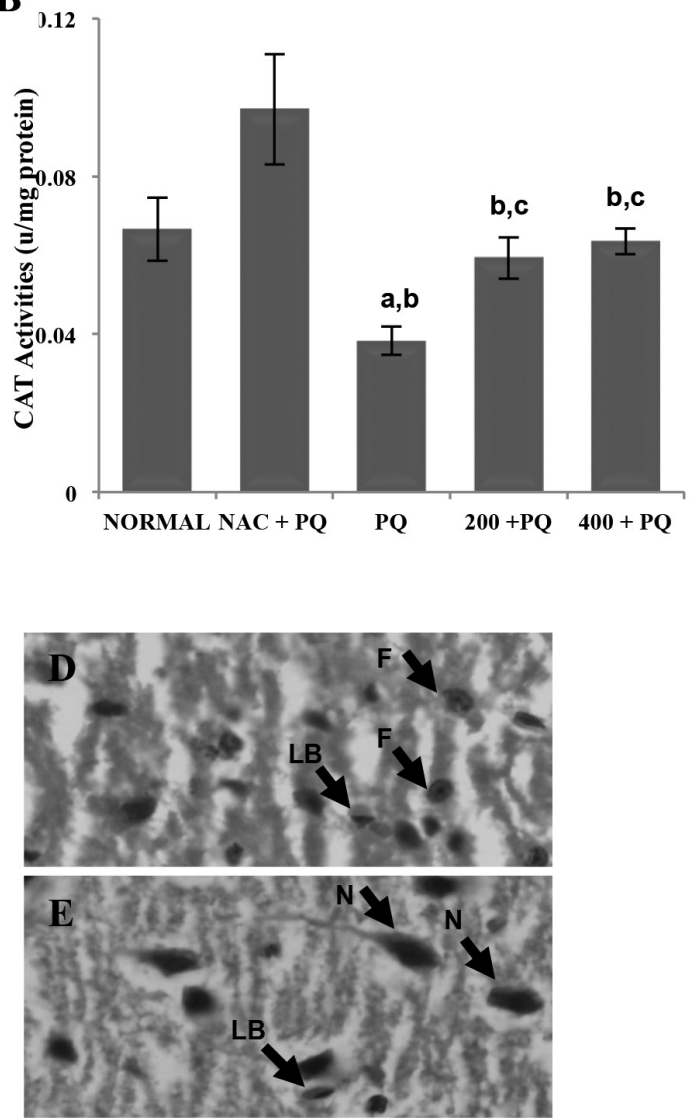

FIGURE 4. Antioxidants status in serum and histopathological observation in substantia nigra. Administrations of PQ for five consecutive days caused significant reductions in the serum SOD (A) and CAT (B) activities ${ }^{\text {a }}$. In contrast, administration with either 200 or 400 $\mathrm{mg} / \mathrm{kg}$ of Z. zerumbet extract significantly increased the activities of these enzymes ${ }^{\mathrm{c}}$. Histological observation of H\&E-stained brain sections in rats treated with PQ (D) for 5 consecutive days showed the presence of neuronal fragmentations and Lewy bodies in the substantia nigra (SN). As for the treatment group, administration of Z. zerumbet extract at the dose of $400 \mathrm{mg} / \mathrm{kg}$ showed intact nucleus with absence of fragmentations, although the presence of Lewy bodies were still apparent (E). Data are presented as mean \pm SEM with ${ }^{\mathrm{a}}$ significant comparison against normal control group $(p<0.05),{ }^{\mathrm{b}}$ significant comparison against positive control group $(\mathrm{NAC}+\mathrm{PQ})(p<0.05)$ and ${ }^{\mathrm{c}}$ significant comparison against PQ-treated group $(p<0.05)$

peroxidation due to its stability. Lipid peroxidation is one of the major products of free radical-mediated injury to brain because of high concentration of polysaturated fatty acid in the brain compared to the other organs (Montine et al. 2002). Malfunction of the antioxidant defense system causes excessive lipid peroxidation process that eventually elevates the level of MDA. The increment in the MDA level is considered as an indicator of cellular damage (Kaplowitz 2000).

Study by Giasson et al. (2002) reported that the marker for oxidative stress such as lipid peroxidation products was increased in the brains of PD patients. Moreover, according to Perfeito et al. (2012), analysis of biochemical markers of oxidative damage in brain tissue samples and postmortem PD patients showed increased levels of MDA and 4-hydroxynonenal in the SN area further confirmed the occurrence of lipid peroxidation. Due to highly electrophilic properties that can react with other biomolecules such as protein and DNA, MDA is considered as a highly toxic molecule that can damage other molecules and eventually causes cell death (Thanan et al 2015). The presence of carbonyl group in proteins may indicate that the proteins are exposed to oxidative stress damage. Alzheimer's disease, chronic lung disease, chronic renal failure, diabetes and sepsis are examples of disorders which are associated with an increase in protein carbonyl content in the tissue (Dalle-Donne et al. 2003; Kadiiska et al. 2005).

In this study, we have proven that administration of ethyl acetate extract of Z. zerumbet at both 200 and 400 $\mathrm{mg} / \mathrm{kg}$ can reduce the level of MDA and PC compared with the PQ-treated group. The ability of these extracts to protect the neurons against lipid peroxidation is supported by studies from Ruslay et al. (2007). The findings of the study reported that ethyl acetate extract of Z.zerumbet able to inhibit lipid peroxidation through its radical scavenging activities. Previous studies on hepatotoprotective (Hamid et al. 2011) and nephroprotective (Abdul Hamid et al. 2012) also corroborated the findings as both studies showed that $Z$. zerumbet ethyl acetate extract reduced the 
level of MDA in both the liver and kidney of chemicallyinduced rats.

In order to protect our body from the free radical toxicity, the production of free radicals are controlled by cellular antioxidant defense mechanisms which include base-enzymatic and non-enzymatic antioxidants (Nordberg \& Arner 2001). Antioxidants are substances that can prevent or slow the oxidation process. The function of antioxidant is to neutralize excess free radicals, protecting the cells against the toxic effects and for disease prevention (Sailaja Rao et al. 2011). Antioxidant enzymes are the first defense systems of cells against oxidative damage.

Activities of CAT and GPX in the SN of the PQ-treated group were significantly lower than the normal control group (negative control). The main key players that provide protection against oxidative stress in the brain are SOD, CAT and GPx (Nikolova 2012). Toxins formed in the brain are usually removed or deactivated by a variety of mechanism of protection. This mechanism however, is compromised in Parkinson's disease when there is a rapid drop in the activities of CAT, GPx and GSH concentrations in the SN (Ogunro et al. 2014). With the failure of the protective mechanism, oxidative stress would easily occur and further causes tissue damage (Chinta et al. 2007). In addition, the activities of SOD and CAT enzymes in the rat serum of PQ-treated group were also lower compared to the normal control group. These results were consistent with the study conducted by Sanyal et al. (2011), in which PD patients have lower antioxidant activity as indicated by significantly decreased level of SOD, CAT and GPX suggesting that the reduction of these enzymes have a correlation with the occurrence of the disease.

There were increased in the activities of SOD, CAT and GPx enzymes in the group of rats given ethyl acetate extract of $Z$. zerumbet. The increment proves that there is an overall enhancement of the endogenous antioxidant defense system in the PQ-treated rats. The results obtained are in line with study by Hamid et al. (2011). In their study, treatment with Z zerumbet at 200 and $400 \mathrm{mg} / \mathrm{kg}$ were also able to increase the superoxide dismutase (SOD) activities in the liver homogenate. The antioxidant activities might be attributed to zerumbone, the main bioactive compound found in the ethyl acetate extract of $Z$. zerumbet. Zerumbone, a sesquiterpene compound and also a potent antioxidant, may indirectly induce glutathione biosynthesis and therefore provides intracellular protection mechanisms through free radical scavenging activity (Ibrahim et al. 2010; Nakamura et al. 2004). However, the increment was more significantly favorable to the $400 \mathrm{mg} / \mathrm{kg}$ group compared to $200 \mathrm{mg} / \mathrm{kg}$. This may be due to excessive production of free radicals following PQ exposure in the SN and the effect of $200 \mathrm{mg}$ / $\mathrm{kg}$ extract of $Z$. zerumbet was insufficient to overcome the detrimental effects of the generated ROS. In all, $Z$. zerumbet proves to have high antioxidant activity through induction of endogenous antioxidant that reduces free radical activity and this can be evidenced by the results of this study. Similarly, this finding is also supported by Hamid et al. (2018) that proved the ability of ethyl acetate extract of $Z$. zerumbet in protecting ethanol-induced brain damages via its antioxidant property.

Substantia nigra (SN) which is located in the midbrain plays a role in controlling motor function. The leading cause of PD is the loss of dopaminergic neuron in substantia nigra pars compacta (Perfeito et al. 2012). Dopaminergic neurons are important to ensure normal motor function. Based on histological observations of the SN, there was a karyolytic feature in the nuclei of neurons in the PQ-treated tissues. Karyolysis is one the characteristics of cell death. According to Gujral et al. (2002), 99\% of cell death is characterized by cell lysis, vacuole formation, karyolysis and karryorhexis (Gujral et al. 2002). Cell death can be due to apoptosis or necrosis. This is supported by research done by Somayajulu-Nitu (2009), which showed that PQ at the dose of $10 \mathrm{mg} / \mathrm{kg} /$ week for 3 weeks had resulted in the death of $65 \%$ dopaminergic neurons in the SN. Similarly, a study conducted by Shimizu et al. (2003) showed that subchronic administration of PQ at the dose of $10 \mathrm{mg} / \mathrm{kg}$ for 5 days was capable of causing death to dopaminergic neurons.

Histological features for ethyl acetate extract of $Z$. zerumbet at the dose of $400 \mathrm{mg} / \mathrm{kg}$ showed that there was no fragmentation detected in the nucleus of the neurons. This indicates that ethyl acetate extract of $Z$. zerumbet at this particular dose may prevent neuronal cell death from occurring. Besides that, the histological hallmark of Parkinson's disease (PD) is the presence of fibrillar aggregates called Lewy bodies (LBS). Formation of LBs is considered to be the indicator for neuronal degeneration because the neuronal loss is found in the predilection sites for LBs (Wakabayashi et al. 2007).

\section{CONCLUSION}

Based on the results obtained, it can be concluded that administration of the ethyl acetate extract of $Z$. zerumbet provides neuroprotective effect on $\mathrm{PQ}$-induced Parkinsonism in rats. The inhibition of oxidative stress was evidenced by reduction of lipid and proteins oxidation and enhanced antioxidant enzyme activities (SOD, CAT and GPx). The most significant effect was observed with the administration of $400 \mathrm{mg} / \mathrm{kg}$ of extract compared to a lower dose of $200 \mathrm{mg} / \mathrm{kg}$. This finding indicates the difference in the presence and amount of antioxidant compounds that contribute significantly to Zingiber zerumbet antioxidant property.

Ethyl acetate extract of $Z$. zerumbet at the dosage of $200 \mathrm{mg} / \mathrm{kg}$ and $400 \mathrm{mg} / \mathrm{kg}$ have been found to prevent oxidative stress and neuronal damage induced by paraquat and therefore, can be developed as a preventive and therapeutic agent for neurodegenerative-induced environmental toxins. The authors have declared no conflict of interest. 


\section{ACKNOWLEDGEMENTS}

This study was by funded by grant FRGS/1/2013/SKK01/ UKM/0/2/1, Biomedical Science Programme, School of Diagnostics and Applied Health Sciences, and Faculty of Health Sciences, UKM.

\section{REFERENCES}

Abdelwahab, S.I., Abdul, A.B., Zain, Z.N. \& Hadi, A.H. 2012. Zerumbone inhibits interleukin- 6 and induces apoptosis and cell cycle arrest in ovarian and cervical cancer cells. International Immunopharmacology 12: 594-602.

Abdelwahab, S.I., Abdul, A.B., Mohan, S., Taha, M.M., Syam, S., Ibrahim, M.Y. \& Mariod, A.A. 2011. Zerumbone induces apoptosis in t-acute lymphoblastic leukemia cells. Leukemia Research 35: 268-271.

Abdul, A.B.H., Al-Zubairi, A.S., Tailan, N.D., Wahab, S.I.A., Zain, Z.N.M., Ruslay, S. \& Syam, M.M. 2008. Anticancer activity of natural compound (zerumbone) extracts from Zingiber zerumbet in human hela cervical cancer cells. Journal of Pharmacology 4: 160-168.

Abdul Hamid, Z., Budin, S.B., Wen Jie, N., Hamid, A., Husain, K. \& Mohamed, J. 2012. Nephroprotective effects of Zingiber zerumbet Smith ethyl acetate extract against paracetamol-induced nephrotoxicity and oxidative stress in rats. Journal of Zhejiang University-Science B (Biomedicine \& Biotechnology) 13(3): 176-185.

Aebi, H. 1984. Catalase in vitro. Methods Enzymol. 105: 121-126.

Batubara, L., Suparto, I.H., Sadiah, S., Matsuoka, R. \& Mitsunaga, T. 2013. Effect of Zingiber zerumbet essential oil and Zerumbone inhalation on body weight of sprague dawley rat. Pakistan Journal of Biological Sciences 16: 1028-1033.

Betteridge, D.J. 2000. What is oxidative stress? Metabolism 49(2 suppl 1): 3-8.

Beyer, W.F. \& Fridovich, I. 1987. Assaying for superoxide dismutase activity: Some large consequences of minor changes in conditions. Anal Biochem. 161(2): 559-566.

Bhuiyan, M.N.I., Chowdhury, J.U.\& Begum, J. 2009. Chemical investigation of the leaf and rhizome essential oils of Zingiber zerumbet (L.) Smith from Bangladesh. Bangladesh Journal of Pharmacology 4: 9-12.

Blanco-Ayala, T., Andérica-Romero, A.C. \& Pedraza-Chaverri, J. 2014. New insights into antioxidant strategies against paraquat toxicity. Free Radical Research 48(6): 623-640.

Blesa, J., Phani, S., Jackson-Lewis, V. \& Przedborski, S. 2012. Classic and new animal models of Parkinson's disease. Journal of Biomedicine and Biotechnology 2012: 1-10.

Bradford, M.M. 1976. A rapid and sensitive method for the quantitation of microgram quantities of protein utilizing the principle of protein-dye binding. Anal Biochem. 72: 248-254.

Brooks, A.I., Chadwick, C.A., Gelbard, H.A., Cory-Slechta, D.A. \& Federoff, H.J. 1999. Paraquat elicited neurobehavioral syndrome caused by dopaminergic neuron loss. Brain Res. 823(1-2): 1-10.

Budin, S.B., Rahmat Sam, M.F., Hamid, A. \& Ghazali, A.R. 2013. Evaluation of the antiradical and antioxidant potential of Zingiber zerumbet rhizome. The Open Conference Proccedings Journal 4: 157.

Cha, E.S., Khang, Y.H. \& Lee, W.J. 2014. Mortality from and incidence of pesticide poisoning in South Korea: Findings from national death and health utilization data between 2006 and 2010. PLoS One 9(4): e95299.
Chinta, J.S., Kumar, M.J., Hsu, M., Rajagopalan, S., Kaur, D., Rane, A., G. Nicholls, D., Choi, J. \& Andersen, J.K 2007. Inducible alterations of glutathione levels in adult dopaminergic midbrain neurons result in nigrostriatal degeneration. The Journal of Neuroscience 27(51): 1399714006.

Coward, D.M., Doggett, N.S. \& Sayers, A.C. 1977. The pharmacology of N-carbamoyl-2-(2,6-dichlorophenyl) acetamidine hydrochloride (LON-954) a new tremorogenic agent. Arzneimittelforschung 27(12): 2326-2332.

Danielson, S.R. \& Anderson, J.K. 2008. Oxidative and nitrative protein modifications in Parkinson's disease. Free Radical Biology \& Medicine 44: 1787-1794.

Dalle-Donne, I., Giustarini, D., Colombo, R., Rossi, R. \& Milzani, A. 2003 Protein carbonylation in human diseases. Trends in Molecular Medicine 9(4): 169-176.

Essa, M.M., Vijayan, R.K., Castellano-Gonzalez, G., Memon, M.A., Braidy, N. \& Guillemin, G.J. 2012. Neuroprotective effects of natural products against Alzheimer's disease. Neurochemical Research 37(9): 1829-1842.

Giasson, B.I., Ischiropoulos, H., Lee, V.M.Y. \& Trojanowski, J.Q. 2002. The relationship between oxidative/nitrative stress and pathological inclusions in Alzheimer's and Parkinson's Disease. Free Radical Biology \& Medicine 32: 1264-1275.

Goldman, S.M., Kamel, F., Ross, G.W., Bhudhikanok, G.S., Hoppin, J.A., Korell, M., Marras, C., Meng, C., Umbach, D.M., Kasten, M., Chade, A.R., Comyns, K., Richards, M.B., Sandler, D.P., Blair, A., Langston, J.W. \& Tanner, C.M. 2012. Genetic modification of the association of paraquat and Parkinson's disease. Movement Disorders 27(13): 1652-1658.

Gujral, S.J., Knight, R.T., Farhood, A., Bajt, M.L. \& Jaeschke, H. 2002. Mode of cell death after acetominophen overdose in mice: Apoptosis or oncotic necrosis? Toxicological Sciences 67: 322-328.

Habsah, M., Amran, M., Mackeen, M.M., Lajis, N.H. \& Kikuzaki, H. 2000. Screening of Zingiberaceae extracts for antimicrobial and antioxidant activities. Journal of Ethnopharmacol. 72: 403-410.

Hamid, A., Budin, S.B., Mohamed, R.A.P., Manaf, N.A., Yuhana, N.Y., Husain, K., Hamid, Z.A. \& Mohamed, J. 2011. Role of oxidative stress in the protective effects of Zingiber zerumbet Smith ethyl-acetate extract against paracetamol-induced hepatotoxicity in sprague-dawley rat. Australian Journal of Basic and Applied Sciences 5(8): 1519-1525.

Hamid, A., Ibrahim, F.W., Teoh, H.M., Nasrom, M.N., Eusoff, N., Husain, K. \& Abdul Latif, M. 2018. Zingiber zerumbet L. (Smith) extract alleviates the ethanol-induced brain damage via its antioxidant activity. BMC Complementary and Alternative Medicine 18(1): 101.

Hirsch, L., Jette, N., Frolkis, A., Steeves, T. \& Pringsheim, T. 2016. The incidence of Parkinson's Disease: A systematic review and meta-analysis. Neuroepidemiology 46(4): 292300.

Huang, C.L., Chao, C.C., Lee, Y.C., Lu, M.K., Cheng, J.J., Yang, Y.C., Wang, V.C., Chang, W.C. \& Huang, N.K. 2016. Paraquat induces cell death through impairing mitochondrial membrane permeability. Molecular Neurobiolology 53(4): 2169-2188

Ibrahim, M.Y., Abdul, A.B.H., Ibrahim, T.A.T., Wahab, S.I.A., Elhassan, M.M. \& Mohan, S. 2010. Attenuation of cisplastininduced nephrotoxicity in rats using zerumbone. African Journal of Biotechnology 9(28): 4434-4441. 
Kadiiska, M.B., Gladen, B.C., Baird, D.D., Germolec, D., Graham, L.B., Parker, C.E., Nyska, A., Wachsman, J.T., Ames, B.N., Basu, S., Brot, N., FitzGerald, G.A., Floyd, R.A., Goerge, M., Heinecke, J.W., Hatch, G.E., Hensley, K., Lawson, J.A., Marnett, L.J., Morrow, J.D., Murray, D.M., Plataras, J., Roberts II, L.J., Rokach, J., Shigenaga, M.K., Sohal, R.S., Sun, J., Tice, R.R., Van Thiel, D.H., Wellner, D., Walter, P.B., Tomer, K.B., Mason, R.P. \& Barrett, J.C 2005. Biomarkers of oxidative stress study II. Are oxidation products of lipids, proteins, and DNA markers of $\mathrm{CCl} 4$ poisoning? Free Radical Biology \& Medicine 38(2005): 698-710.

Kaplowitz, N. 2000. Mechanism of liver cell injury. Journal of Hepatology 32(S1): 39-47.

Lascano, R., Muñoz, N., Robert, G.N., Rodriguez, M., Melchiorre, M., Trippi, V. \& Querol, G. 2012. Paraquat: An oxidative stress inducer. Herbicides - Properties, Synthesis and Control of Weeds. Rijeka, Croatia: InTech. pp. 135-148.

Ledwozyw, A., Michalak, J., Stepień, A. \& Kadziołka, A. 1986. The relationship between plasma triglycerides, cholesterol, total lipids and lipid peroxidation products during human atherosclerosis. Clin Chim Acta. 155(3): 275-283.

Levine, R.L., Garland, D., Oliver, C.N., Amici, A., Climent, I., Lenz, A.G., Ahn, B.W., Shaltiel, S. \& Stadtman, E.R. 1990. Determination of carbonyl content in oxidatively modified protein. Methods Enzymol. 186: 464-478.

Lewis, A.P. \& Cookson, R.M. 2012. Gene expression in the Parkinson's Disease brain. Brain Research Bulletin 88(2012): 302-312.

McCollum, M., Ma, Z., Cohen, E., Leon, R., Tao, R., Wu, J.Y., Maharaj, D. \& Wei, J. 2010. Post-MPTP treatment with granulocyte colony-stimulating factor improves nigrostriatal function in the mouse model of parkinson's disease. Molecular Neurobiology 41: 410-419.

Montine, T., Neely, M., Quinn, J., Beal, M., Markesbery, W., Roberts, L. \& Morrow, J. 2002. Lipid peroxidation in aging brain and Alzheimer's Disease. Free Radical Biology \& Medicine 33(5): 620-626.

Nakamura, Y., Yoshida, C., Murakami, A., Ohigashi, H., Osawa, T. \& Uchida, K. 2004. Zerumbone, a tropical ginger sesquiterpene, activates phase II drug metabolizing enzymes. FEBS Letter 572(1-3): 245-250.

Nikolova, G. 2012. Oxidative stress and Parkinson disease. Trakia Journal of Sciences 10: 92-100.

Nordberg, J. \& Arner, E.S. 2001. Reactive oxygen species, antioxidants, and the mammalian thioredoxin system. Free Radical Biology \& Medicine 31: 1287-1312.

Ogunro, P.S., Mustapha, A.F., Oshodi, T.T., Adebayo, R.A., Atiba, A.S., Akande, J.O. \& Oke, O.Z. 2014. Alteration in antioxidants level and lipid peroxidation of patients with neurodegenerative diseases \{Alzheimer's disease and Parkinson disease\}. International Journal of Nutrition, Pharmacology, Neurological Diseases 4(3): 146-152.

Perfeito, R., Cunha-Oliveira, T. \& Rego, C.A. 2012. Revisiting oxidative stress and mitochondrial dysfunction in the pathogenesis of Parkinson disease-resemblance to the effect of amphetamine drugs of abuse. Free Radical Biology \& Medicine 53(9): 1791-1806.

Poljsak, B., Suput, D. \& Milisav, I. 2013. Achieving the balance between ROS and antioxidants: When to use the synthetic antioxidants. Oxidative Medicine and Cellular Longevity 2013: 956792.
Rao, P.S., Kalva, S., Yerramilli, A. \& Mamidi, S. 2011. Free radicals and tissue damage: Role of antioxidants. Free Radical and Antioxidant 1(4): 2-7.

Ruslay, S., Abas, F., Shaari, K., Zainal, Z., Maulidiani, Sirat, H., Israf, D.A. \& Lajis, N.H. 2007. Characterization of the components present in the active fractions of health gingers (Curcuma xanthorrhiza and Zingiber zerumbet) by HPLCDAD-ESIMS. Food Chemistry 104: 1183-1191.

Sanyal, J., Sarkar, B., Banerjee, T.K., Mukherjee, S.C., Ray, B.C. \& Rao, V.R. 2011. Peripheral markers for oxidative stress in Parkinson's Disease patients of Eastern India. Neurochemical Journal 5(2): 146-149.

Seet, R.C.S., Lee, C.Y.J., Lim, E.C.H., Tan, J.J.H., Quek, A.M.L., Chong, W.L., Looi, W.F., Huang, S.H., Wang, H., Chan, Y.H. \& Halliwel, B. 2010. Oxidative damage in Parkinson Disease: Measurement using accurate biomarkers. Free Radical Biology \& Medicine 48: 560-566.

Shafique, H., Blagrove, A., Chung, A.\& Logendrarajah, R. 2011. Causes of Parkinson's Disease: Literature review. Journal of Parkinsonism \& Restless Legs Syndrome 1(1): 7-9.

Shimizu, K., Matsubara, K., Ohtaki, K., Fujimaru, S., Siato, O. \& Shiono, H. 2003. Paraquat induces long-lasting dopamine overflow through the excitotoxic pathway in the striatum of freely moving rats. Brain Research 976(2): 243-252.

Somayajulu-Nitu, M., Sandhu, J.K., Cohen, J., Sikorska, M., Sridhar, T., Matei, A., Borowy-Borowski, H. \& Pandey, S. 2009. Paraquat induces oxidative stress, neuronal loss in substantia nigra region and Parkinsonism in adult rats: Neuroprotection and amelioration of symptoms by watersoluble formulation of Coenzyme Q10. BMC Neuroscience 10: $1-12$.

Somchit, M.N., Shukriyah, M.H.N., Bustamam, A.A. \& Zuraini, A. 2005. Anti pyretic and analgesic activity of Zingiber zerumbet. International Journal of Pharmacology 1: 277-280.

Somchit, M.N., Mak, J.H., Ahmad Bustamam, A., Zuraini, A., Arifah, A.K., Adam, Y. \& Zakaria,Z.A. 2012. Zerumbone isolated from Zingiber zerumbet inhibits inflammation and pain in rats. Journal of Medicinal Plants Research 6(2): 177-180.

Thannan, R., Oikawa, S., Hiraku, Y., Ohnishi, S., Ma, N., Pinlaor, S., Yangvanit, P., Kawanishi, S. \& Murata, M. 2015. Oxidative stress and its significant roles in neurodegenerative diseases and cancer. International Journal of Molecular Sciences 16: 193-217.

Wakabayashi, K., Tanji, K., Mori, F. \& Takahasi, H. 2007. The Lewy body in Parkinson's disease: Molecules implicated in the formation and degradation of alpha-synuclein aggregates. Neuropathology 27(5): 494-506.

Wesseling, C., van Wendel, de Joode B., Ruepert, C., León, C., Monge, P., Hermosillo, H. \& Partanen, T.J. 2001. Paraquat in developing countries. Int. J. Occup. Environ. Health. 7(4): 275-286.

Yang, W. \& Tiffany-Castiglioni, E. 2005. The bipyridyl herbicide paraquat produces oxidative stress-mediated toxicity in human neuroblastoma SH-SY5Y cells: Relevance to the dopaminergic pathogenesis. Journal of Toxicology and Environmental Health Part A 68(22): 1939-1961.

Yob, N.J., Jofrry, S.M., Affandi, M.M., Teh,L.K., Salleh, M.Z. \& Zakaria, Z.A. 2011. Zingiber zerumbet (L.) Smith: A review of its ethnomedicinal, chemical, and pharmacological uses. Evidence-Based Complementary and Alternative Medicine: eCAM 2011: 543216. 
Yokoyama, H., Kuroiwa, H., Yano, R. \& Araki, T. 2008. Targeting reactive oxygen species, reactive nitrogen species and inflammation in MPTP neurotoxicity and Parkinson's disease. Neurolological Sciencs 29: 293-301.

Biomedical Science Programme

Center for Health \& Applied Sciences

Faculty of Health Sciences

Universiti Kebangsaan Malaysia, Jalan Raja Muda Abdul Aziz

50300 Kuala Lumpur, Federal Territory

Malaysia
*Corresponding author; email: asmah0901@ukm.edu.my

Received: 14 March 2018

Accepted: 5 June 2018 